\title{
呼吸障害で発症した下咽頭・喉頭良性腫瘍
}

\author{
鈴木 弥生 ${ }^{1)}$ •戸島 均2)・市村 恵一3)
}

\section{Epiglottic Pleomorphic Adenoma and Hypopharyngeal Lipoma Causing Airway Obstruction}

\author{
Yayoi Suzuki \\ (University of Tokyo) \\ Hitoshi Tojima \\ (Hitachi General Hospital) \\ Keiichi Ichimura \\ (Jichi Medical School)
}

Only a few cases of benign tumors in the larynx and hypopharynx have been reported in the literature. Benign tumors in this area can take prolonged courses and may cause serious consequences. This report discusses a case of pleomorphic adenoma of the larynx and a case of large hypopharyngeal lipoma both of which resulted in sudden airway obstruction.

Case 1 was a 47 -year-old male who complained of a sore throat while swallowing. A yellow, large smooth tumor in the epiglottis expanding from glottic surface to laryngeal surface was revealed using fiberscopy. Immunohistochemistry of the biopsy specimen suggested the tumor was a pleomorphic adenoma, and subsequently a treacheostomy was performed to relieve the airway obstruction. The tumor was completely excised via a horizontal laryngectomy.

Case 2 was a 58-year-old female who experienced suffocation while eating. Fiberscopy showed a yellow, large smooth tumor expanding from hypopharynx to aryepiglottic fold. Biopsy and an emergency tracheostomy was performed. The tumor was removed completely via a lateral pharyngotomy approach. The $5.5 \times 4.3 \times 2.7 \mathrm{~cm}$ tumor was pathologically diagnosed as lipoma, and was contained within the thyropharyngeal muscle, intramuscular type.

Key words : pleomorphic adenoma, lipoma, benign tumor, larynx, hypopharynx

はじめに

下咽頭・喉頭領域の良性腫瘍の報告は比較的少ない. 多形腺腫は耳下腺に発生することが多いが他の部位では 少なく，喉頭蓋に生じたものは本邦で 6 例報告されてい るのみである。また脂肪腫は良性腫瘍のなかでは頻度の 高い腫瘍であるが，下咽頭に発生した報告は15例程度で ある. 今回, われわれは呼吸障害を呈した喉頭・下咽頭
良性腫瘍，すなわち喉頭蓋に生じた多形腺腫の 1 例执よ び下咽頭の巨大脂肪腫の 1 例を経験したので文献的考察 とともに報告する.

\section{症例}

症例 $1 ： 47$ 歳, 男性.

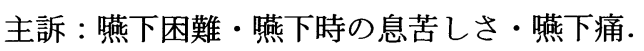

1) 東京大学耳鼻咽喉科学教室

2）日立製作所日立総合病院耳鼻咽喉科

3）自治医科大学耳鼻咽喉科学教室 


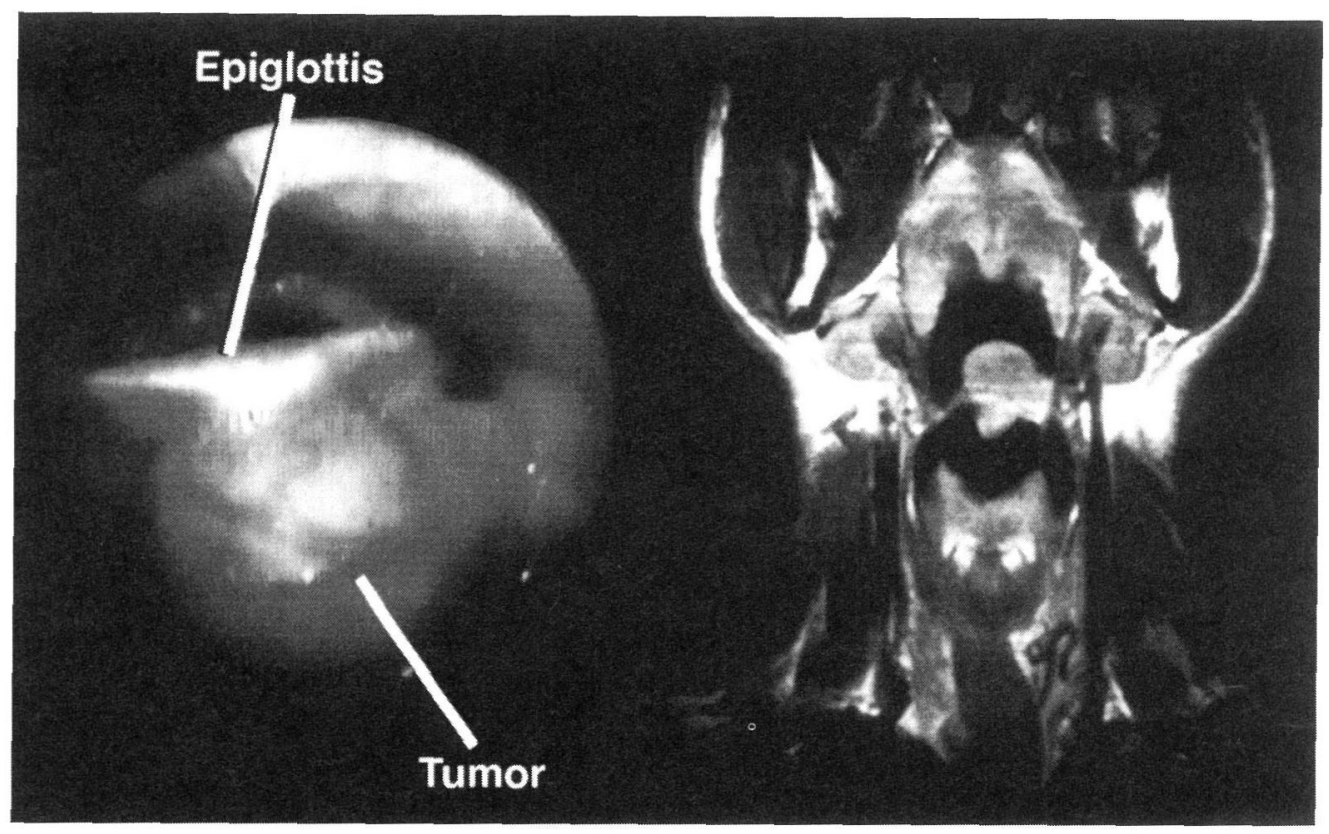

図 1 症例 1 の初䛦時所見

（左）喉頭フォイバースコピー所見：喉頭蓋舌面から喉頭面にまたがる表面平滑，黄色球形の 腫瘤.

（右）MRI T2 強調冠状断像：高輝度の陰影が矦頭蓋の両面に進展して招り, 内部は不均一で ある。

既往歴・家族歴 : 特記すべきことなし.

生活歴: 飲酒 日本酒 $1 \sim 2$ 合/日，契煙 タバコ20 本/日。

現病歴： 1 年程前より飲み込みにくいなどの症状を自 覚. 最近, 食餌嚥下後に一瞬, 息苦しさを感じることが めった。初診の 4 日前, 嬹下痛が出現し, 近医耳鼻咽喉 科に扣いて喉頭蓋の腫瘍を指摘され，精査加療のため当 院を紹介受診した。

初診時現症 : 話声は含み声。全身所見では特に異常を 認めない。一般血液検査, 心電図, 胸部 $\mathrm{X}$ 線像に異常を 認めない。

局所所見（図 1)：喉頭ファイバースコピーでは，喉頭 蓋舌面加喉頭面へ貫通する表面平滑，黄色球形の腫瘤 を認めた。CTでは，喉頭蓋中央〜左半分から左喉頭蓋 谷に進展する腫瘤を認める、頸部リンパ節腫脹なし。 MRI では, T1 強調画像で比較的低輝度, T2 強調画像 で高輝度の腫瘤を認め, 矢状断画像では喉頭蓋の両面に 進展していた。

経過：鱟下時呼吸困難の恐れがあるため気管切開を行 い，喉頭直達鏡下に生検を施行した。喉頭蓋の左側に腫
瘍が存在して括り，充実性であった。病理組織学的検查 では多形腺腫ないしカルチノイド腫瘍が疑われた。

平成 10 年 9 月に腫瘍摘出術を施行した。頸部を外切開, 経舌骨的にアプローチし，喉頭上水平部分切除を行った. 腫瘍は最大径 $4 \mathrm{~cm}$, 喉頭蓋を舌面から喉頭面に貫通し, 被膜に包东れていた(図2).

術後は経口摂取に問題なく気管切開孔を閉じて退院し， 経過順調である。

病理組織学的診断（図 3 )：好酸性の胞体を持ち, 一部 intracytoplasmic lumen に容れる. 粘液腫様の間質を持 つ部分と澼平上皮への分化を示す部分が混在し，多形腺 腫と診断された。免疫染色では NSE $(+)$, S-100 (+), サ イトケラチン $(+)$, chromogranin $\mathrm{A}( \pm)$, Fontana-Masson(-), Grimelius(-), CEA(一), EMA(ー)であった.

症例 $2: 58$ 歳, 女性.

主訴 : 嗄声, 嚥下困難, 鱟下時の呼吸困難.

既往歴：高血圧，高コレステロール血症で加療中.

家族歷：特記すべきことなし。

生活歴：飲酒, 制煙ともになし.

現病歷： 1 年前より声が出しづらい，飲久込みにくい 

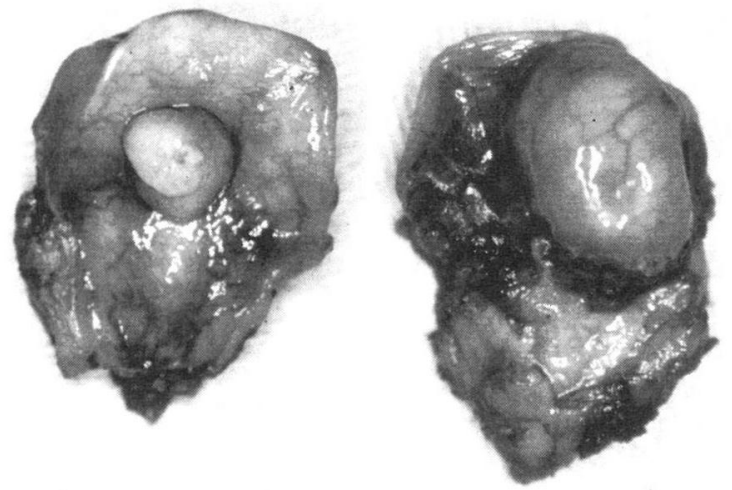

図 2 摘出標本 (左 : 喉頭蓋喉頭面, 右 : 喉頭蓋舌面) 腫瘍は最大径 $4 \mathrm{~cm}$, 喉頭蓋舌面から喉頭面に及び, 被 膜に包まれていた。

などの症状が出現した。初診の 4 日前, 食事中一過性に 呼吸ができない状態に宿ったため，精査加療を希望し当 院受診した.

初診時現症：話声は含夕声。全身所見上特飞異常を認 めない。一般血液検査, 心電図, 胸部 X線像に異常を認 めない。

局所所見：喉頭ファイバーにて観察すると声門上部に 黄色球形の腫瘤が認められ，これが㬵頭入口部をほぼ閉 塞していた(図 4). 画像上は, 咽頭造影では下咽頭前壁 から咽頭腔に充満して存在する腫瘤, 造影 CT 軸位断で

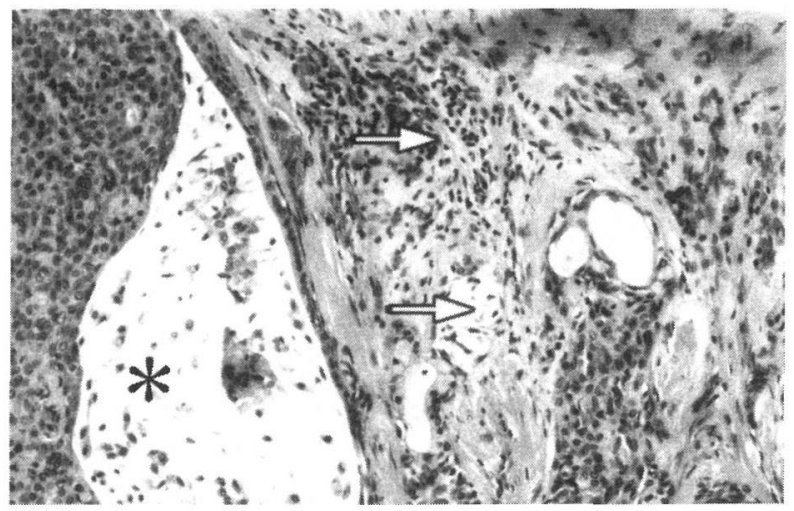

図 3 病理組織所見 $(\mathrm{HE}$ 染色, $\times 10)$

好酸性の胞体を持ち, 一部 intracytoplasmic lumen 飞容 れる，粘液腫様の間質を持つ部分 (*印), 扁平上皮への 分化を示す部分 (矢印)が混在し多形腺腫に特徵的であ る.

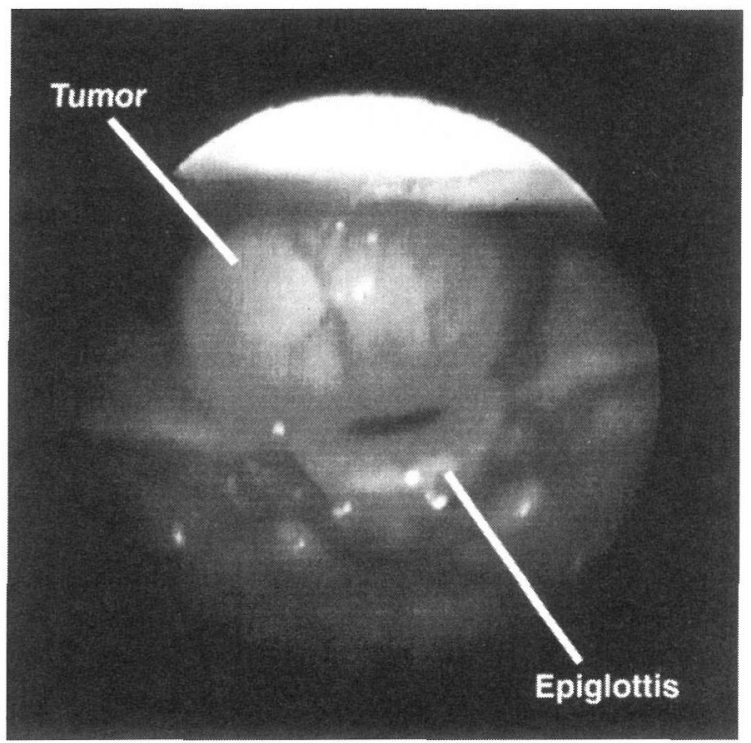

図4症例 2 の初診時喉頭ファイバースコピー所見 喉頭腔の黄色球形の腫瘤が喉頭入口部をほぼ閉塞する。

は，下咽頭の右側披裂部から対側披裂部まで広がる低密 度領域，MRI では，T1 強調，T2 強調ともに高信号を 呈する境界明瞭な領域を認めた（図 5 ).

経過：気道確保のため気管切開を行い，硬性喉頭鏡下 飞生検を施行した。腫瘍は弾性軟，黄色の表面平滑の腫 瘤で，被膜を有していた．大きかったため茎が披裂部〜 後壁のぞこに山るかは確認できなかった。病理組織学的 検査では核の異型性は認められず，脂肪腫と診断された。

平成10年 10 月全身麻酔下に腫瘍摘出術を施行した。胸 鎖乳突筋前縁に沿って右頸部切開しアプローチしたとこ ろ，甲状咽頭筋筋層内に被膜に包屯れた黄色の腫瘤を認 めた(図 6 )。腫瘍は対側披裂部まで広がり，喉頭を圧排 していた，反回神経を輪状甲状間膜貫通部まで確認保存 した後, 腫瘍の被膜に沿って剥離を進めたところ, 周囲 との癒着はほとえど認められなかった。被膜は披裂軟骨 に接していたが，剥離可能であった。生検を行った 1 カ 所は粘膜との癒着が強かったため一部の咽頭粘膜を合併 切除した。粘膜切除部を縫合閉鎖し，創を 2 層に縫合し 手術を終了した。

術後は患側の声帯は固定するも経口摂取に問題なく, 気切孔を閉鎖し退院となった。

病理診断: $5.5 \times 4.3 \times 2.7 \mathrm{~cm}$ の腫瘍. 被膜に包委机, 割面は脂肪調を呈する。組織学的には, 薄い血管線維組 織で画された成熟した脂肪組織でめった。 


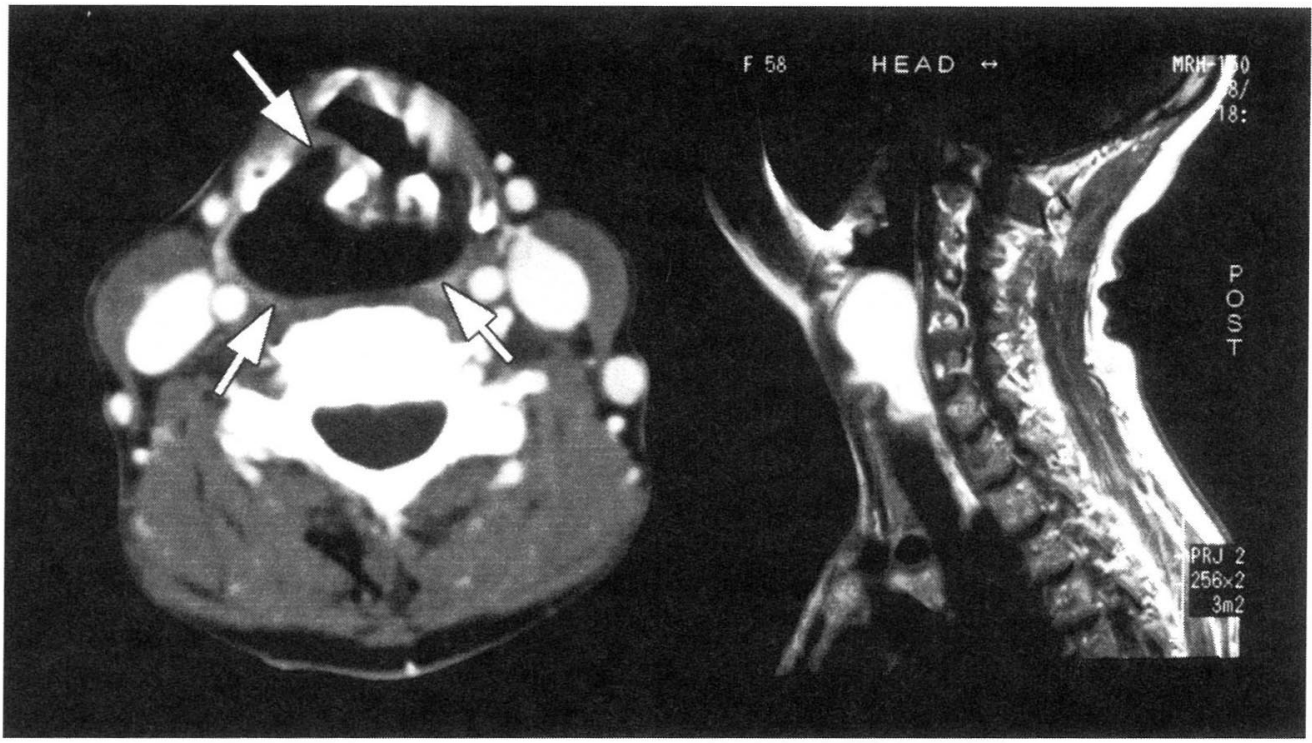

図 5 症例 2 の画像所見

（左）造影 CT 軸位断像. 右下咽頭の披裂部から後壁を経て対側まで広がる低密度領域. 喉頭 は圧排されている。

（右）MRI T2 強調矢状断像. 下咽頭に充満する高信号の境界明瞭な領域.

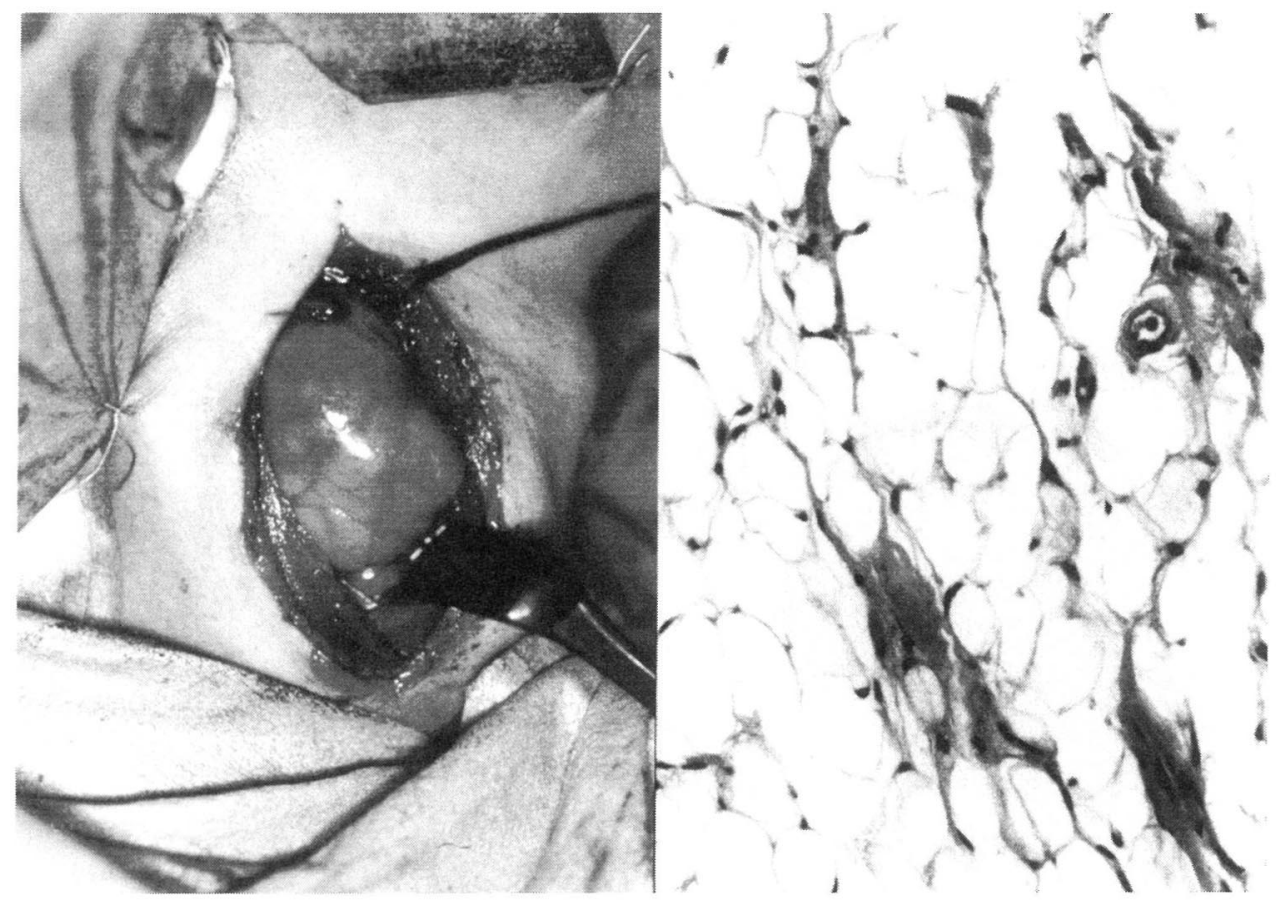

図 6 術中所見扣よび病理組織標本 $(\mathrm{HE}$ 染色, $\times 20)$

（左）右頸部を切開してアプローチした。甲状咽頭筋筋層内に被膜に包まれた黄色の腫瘤 を認めた．大きさ $5.5 \times 4.3 \times 2.7 \mathrm{~cm}$, 周囲との癒着はなかった。

（右）薄い血管線維組織で画された成熟した脂肪組織. 


\section{考察}

症例 1 は47歳男性の喉頭蓋に発生した多形腺腫, 症例 2 は58歳女性の下咽頭に発生した巨大脂肪腫であった。 いずれも受診直前に燕下時の気道閉塞症状を示して扣り， 治療には外切開法による腫瘍摘出術を必要とした。

多形腺腫は耳鼻咽喉科領域では耳下腺などの大唾液腺 に多く発生する．従来の報告の集計では $92.5 \%$ が大唾液 腺由来であり ${ }^{1)}$, なかでも耳下腺が $46 \sim 75 \%$ を占める2). 喉頭多形腺腫の報告は少なく,太田ら ${ }^{3)}$ の調查では, 今 までに本邦で10例 (らち喉頭蓋 6 例)の喉頭多形腺腫が報 告されているのみである. 海外の症例も少なく, 声門下 に生じたものが散見される程度である4)5. 症例 1 では, 腫瘍が喉頭蓋を貫通し, 舌面および喉頭面の両面への発 育を示した点が特徵的であった。しかし組織標本では軟 骨への浸潤像は認められなかった．解剖学的には喉頭蓋 軟骨は多孔性であることが知られて特り6)，この孔を経 由して進展したものと考兄られた. 斎田られも喉頭蓋喉 頭面〜喉頭蓋谷へと進展した症例を報告している.

脂肪腫は, 四肢, 軀幹の皮下に多い限局性腫瘤で, 軟 部組織腫瘍では最も頻度が高い，骨格筋に関係する脂肪 腫は, intramuscular type 括よび intermuscular type そ 分けられ ${ }^{8)}$, さらに intramuscular type は infiltrating type（横紋筋組織内に浸潤増殖するるの）, non-infiltrating type (結合織の被膜に覆われ浸潤のないもの)に分類 できる9．症例 2 は甲状咽頭筋内に被膜に包まれた腫瘍 が発生しており, intramuscular non-infiltrating type に 属すると考兄られた．脂肪腫は下咽頭領域に発生するこ とはまれである. 本邦では現在までに約15症例の下咽頭 脂肪腫が報告されているのみであり，海外での報告例も
少ない。しかし，下咽頭から進展した脂肪腫が喉頭脂肪 腫として報告されることも多く，また本症例のように喉 頭蓋型と下咽頭型の区別は厳密には不可能であるため10), 実際の下咽頭脂肪腫の症例数はこれより多い可能性もあ る. 過去の文献を渉猟したところ, 披裂部〜下咽頭部の 脂肪腫について詳細な記載のあった症例は23例存在した。 このらち 5 症例で呼吸障害を呈していた(表 1$)^{11) ~ 16) . ~}$

喉頭・下咽頭良性腫瘍の診断には MRI などの画像検 查も有効だが3)，確定診断には直達喉頭鏡下に生検を行 い，できるだけ大きな検体を採取することが必須である。 多形腺腫はその多形性のため検体が小さいと組織診断が 難しく，また多形腺腫内癌腫が存在することもある1718). 脂肪腫については, 脂肪肉腫との鑑別が困難な例が報告 されている.

本疾患の治療にあたっては，下咽頭の解剖学的位置お よび良性腫瘍が長期間にわたり増大しらることを考慮し， 呼吸障害の発生に十分な注意をはらら必要がある．無症 状に経過し，突然重篤な症状で発見されることがある14). Mansson ら ${ }^{19)}$ は治療開始前に窒息のため死亡した 2 例 を報告している，本症例に扣いても一時的な窒息状態に 陷って扣り, 術前の気道狭窄の正確な評価と気道確保の 重要性を再認識させられた。

喉頭・下咽頭領域の良性腫瘍は頻度が少ないため，手 術方法は必ずしも確立されたものではない，喉頭多形腺 腫に関しては，今までの本邦の症例では喉頭微細手術な いし外切開により腫瘍を摘出したとする報告が多い。最 近ではレーザーの使用も推桨されている．再発ないし悪 性転化は核出手術症例拉よび手術中に被膜が破れ, 細胞 播種が起こった症例に多いといわれて拉り，初回手術で

表 1 過去に発表された披裂部〜下咽頭領域の脂肪腫症例. 呼吸障害を呈したもの.

\begin{tabular}{|c|c|c|c|c|c|c|c|c|c|c|c|}
\hline & 報告者 & 発表年 & 年此命 & 性別 & 主 & 発生部位 & 型 & 大きさ & 治療法 & 組織診断 & 備 \\
\hline 1 & 滰野ら11) & 1960 & 36 & 女 & $\begin{array}{l}\text { 咽頭異物感, 䱏下 } \\
\text { 困難, 呼困難 }\end{array}$ & $\begin{array}{l}\text { 下咽頭後壁 } \\
\text { 右側 }\end{array}$ & 有茎性 & $7.5 \mathrm{~g}$ & 口内 & 脂肪腫症 & \\
\hline 2 & $\begin{array}{l}\text { 焦ら } \\
\text { 松田ら }\end{array}$ & $\begin{array}{l}1976 \\
1990\end{array}$ & 43 & 男 & $\begin{array}{l}\text { 喉頭異物感, 噯下 } \\
\text { 凐度呼吸難 }\end{array}$ & 左披裂部 & 広基性 & $\begin{array}{l}21 \mathrm{~g} \\
5 \times 3 \times 0.5 \mathrm{~cm}\end{array}$ & $\begin{array}{l}\text { 口内 } 3 \text { 回 } \\
\text { (laser) } \\
\text { 外切開 } 1 \text { 回 }\end{array}$ & 脂肪腫 & 同一症例再発 \\
\hline 3 & 岡部 ${ }^{14)}$ & 1989 & $?$ & $?$ & 呼吸困難 & $?$ & $?$ & $?$ & 口内 & 脂肪腫 & \\
\hline 4 & 橘ら & 1994 & 69 & 女 & $\begin{array}{l}\text { 嚥下障害, 労作時 } \\
\text { 呼吸困難 }\end{array}$ & 後壁 & 粘膜下 & $3 \times 2.5 \times 2 \mathrm{~cm}$ & $\begin{array}{l}\text { 口内 } 7 \text { 回 } \\
\text { 外切開 } 2 \text { 回 }\end{array}$ & 脂肪腫 & 再発 \\
\hline 5 & 菅ら 16$) *$ & 1994 & 64 & 男 & 呼吸困難 & $\begin{array}{l}\text { 右披裂喉頭 } \\
\text { 愠ヒダ }\end{array}$ & 広基性 & $6 \times 7.5 \times 5 \mathrm{~cm}$ & 口内 & $\begin{array}{l}\text { 紡錘形細胞 } \\
\text { 脂肪腫 }\end{array}$ & $\begin{array}{l}\text { 頸部脂肪腫 } \\
\text { 摘出後再例 }\end{array}$ \\
\hline
\end{tabular}

* 印の症例は喉頭脂肪腫として発表されているもの. 
の完全摘出が必要である. 症例 1 では, 経舌骨的に声門 上喉頭水平部分切除術を行らことで十分な視野が得られ， 腫瘍を周囲組織をつけて完全摘出することができた。

脂肪腫の治療法としては, 口内法 (喉頭直達鏡下に絞 断器を用いたものが多い), および外切開法を行ったも の双方が報告されている．腫瘍が大きい場合には外切開 により十分な視野をとることが必要である20). 脂肪腫も 完全摘出すれば再発はまれとされている21)が, 完全摘 出できなかった例で再発を繰り返したもの1315)など今 回渉椫した 23 例では再発例が 5 例報告されていた. 特に 症例 2 のような intramuscular type は位置的に完全摘 出が難しいため再発率が高く22), なかでも non-infiltrating type は再発率が高く長期間経過後の再発があるとい われており15)，今回のように外切開法による完全摘出を 行らべきであると考兄られた。

症例 1 の今後の経過钼察に括いては, 多形腺腫の再発 率の高さを考慮に入れる必要がある. 再発率が高い原因 としては, 多形腺腫では主腫瘤の被膜外に娘結節が存在 することがあり，また被膜を破って進展する例が多いた め23)といわれて和り，本症例のように被膜内ではある が喉頭蓋の両面への発育を示すような症例では今後注意 を要する，悪性転化例も報告されて括り7)24425)，長期間 の経過観察が必要と考兄られる. 症例 2 の脂肪腫に関 しても, 再発を繰り返すうちに脂肪肉腫に変化した症 例926)27) も報告されており，長期にわたって経過を観察 していく必要がある.

\section{結 論}

1. 呼吸障害を呈した喉頭および下咽頭の良性腫瘍を 経験したので報告した。

2 . 症例 1 は 47 歳男性, 喉頭蓋舌面〜喉頭面に及ぶ表 面平滑, 黄色球形の腫瘤があり, 声門上喉頭水平部分切 除により完全摘出がなされた。病理診断は多形腺腫で あった。

3 . 症例 2 は58歳女性, 燕下時の呼吸障害にて発症し た. 甲状咽頭筋内に発生した腫瘍が喉頭上部をほぼ閉塞 していたが，外切開(側切開法)により完全に摘出できた. 病理学的には脂肪腫であり, intramuscular type (noninfiltrating type) であった.

4. 喉頭・下咽頭の良性腫瘍は, 長期間無症状に発育 乙突然重篤な症状を呈することがある。診断・治療方針 決定・呼吸障害防止のためには生検および術前の気管切
開が有効と考兄られた.

稿を終觉るにあたり, 御指導, 御校閲を賜りました東京大学 医学部耳鼻咽喉科学教室・鉿木光也先生, 病理学上の御教示を 頂いた日立総合病院病理科・鴨志田敏郎先生，御助力を賜りま した筑波大学医学部耳鼻咽喉科学教室・辻茂希先生に深く感謝 いたします。

\section{参考文献}

1) 大久保泰, 三橋重信, 平野 実: 喉頭蓋に発生した多形腺 腫の一症例. 耳鼻 $27: 680 \sim 684,1981$.

2 ) Cotelingam JD, Barnes L and Nixon V : Pleomorphic adenoma of the epiglottis. Arch Otolaryngol $103: 245 \sim 247$, 1977.

3 ) 太田 康, 仙波哲雄, 伊藤 健, 他 : 搌頭蓋多形腺腫例. 耳鼻臨床 88 : 1067 1071, 1995.

4) Jokinen K, Seppala A and Palva A : Laryngeal pleomorphic adenoma. J Laryngol Otol 88 : 1131 1134, 1974.

5 ) Argat M, Born I, Maier H, et al : Pleomorphic adenoma of the larynx. Eur Arch Otorhinolaryngol $251: 304 \sim 306$, 1994.

6) 解剖 一喉頭軟骨一. 臨床耳鼻咽喉科学 1 基礎編（沢木修 二, 設楽哲也, 野村恭也, 編). 312 327頁, 中外医学社, 東京, 1976.

7 ）斎田春人, 鈴木吾登武, 飯田祐起子, 他 : 喉頭の悪性多形 腺腫の 1 症例. 耳展 $33: 249 \sim 254,1990$.

8 ) Deschler D, Lee K and Tami T : Laryngeal infiltrating intramuscular lipoma. Otolaryngol Head Neck Surg 108 : 374 377, 1993.

9 ) Eisele D and Landis G : Retropharyngeal infiltrating lipoma - a case report. Head Neck Surg $10: 416 \sim 421,1988$.

10) Harper A : Lipomata of the upper air and food passages. J Laryngol Otol $73:$ 419 422, 1959.

11）滝野賢一, 日野原正：下咽頭良性腫瘍 Lipomatose 91 治 験例. 耳展 $3: 362 \sim 364,1960$.

12）進 武幹, 野副 功, 大沢弘明, 他: 長期にわたり再発を くり返した下咽頭腫瘍の一症例. 耳鼻 $22 ： 202 \sim 209,1976$.

13）松田知愛, 森川郁郎, 進 武幹: 再発を繰り返した喉頭脂 肪腫の 1 例. 耳鼻 $36: 1022 \sim 1026,1990$.

14）岡部か上子, 桐山眞樹, 勝見容子, 他 : 呼吸障害を来した 下咽頭脂肪腫症例. 日耳鼻 $92: 965,1989$.

15）橘 敏郎, 徳永雅一, 江崎史朗, 他: 再発を繰り返した巨 大後咽頭脂肪腫の一症例. 耳展 $37: 531 \sim 534,1994$.

16）菅 喜郎，梅野祐芳，野田哲哉：喉頭に発生した脂肪腫の 1例. 耳鼻 $40: 765 \sim 768,1994$.

17）松井克明, 橋本公夫, 岡本公夫, 他: 喉頭に発生したまれ 有な悪性多形腺腫 (malignant pleomorphic adenoma) の 1 
例について. 耳鼻 $28: 454 \sim 457,1982$.

18）加藤 拓, 高橋久雄, 井田喜博, 他: 唾液腺病変の穿刺吸 引細胞診. 臨床病理 $42: 648 \sim 655,1994$.

19) Mansson I, Wilske $J$ and Kindblom $L$ : Lipoma of the hypopharynx. J Laryngol Otol $92: 1037 \sim 1043,1978$.

20）山川純至, 折田洋造, 林 环巳, 他 : 咽喉頭異常感を主訴 とした咽頭良性腫瘍の 1 症例. 耳鼻臨床 補 $31: 77 \sim 80$, 1989.

21) Wenig BM and Heffner DK : Liposarcomas of the larynx and hypopharynx ; a clinicopathologic study of eight new cases and a review of the literature. Laryngoscope 105 : 747 756, 1995.

22) Chen $K$ and Weinberg $R$ : Intramuscular lipoma of the larynx. Am J Otolaryngol $5: 71 \sim 72,1984$.

23）安田範夫 : 耳下腺多形腺腫の治療一多発性再発腫瘍の切 除手術一. JOHNS $13: 79 \sim 85,1997$.
24) Sabri J and Hajjar M : Malignant mixed tumor of the vocal cord. Arch Otolaryngol $85: 832 \sim 834,1967$.

25) Milford C, Mugliston T, O'Flynn P, et al : Carcinoma arising in a pleomorphic adenoma of the epiglottis. $\mathrm{J}$ Laryngol Otol $103: 324 \sim 327,1989$.

26) Kapur $T$ : Recurrent lipomata of the larynx and the pharynx with late malignant change. J Laryngol Otol $82: 761 \sim 768,1968$.

27）末広倫夫, 斎藤龍介, 藤田 彰, 他 : 副咽頭間隙 atypical lipoma の 1 例. 耳喉 $59: 41 \sim 48,1987$.

$$
\left(\begin{array}{l}
\text { 原稿受付 : 平成 } 12 \text { 年 } 9 \text { 月 } 27 \text { 日 } \\
\text { 原稿採択 : 平成12年12月 } 20 \text { 日 } \\
\text { 別刷請求先 : 鈴木弥生 } \\
\text { 干113-8655 東京都文京区本郷7-3-1 } \\
\text { 東京大学医学部耳鼻咽喉科学教室 }
\end{array}\right)
$$

